\title{
Kajian Perbandingan Penggunaan Berbagai Merek Semen Dengan Dan Tanpa Perawatan Terhadap Kuat Tekan Dan Kuat Lentur Beton Pada Perkerasan Kaku
}

\author{
Comparative Study on the Use of Various Brands of Cement with and without Treatment of \\ compresive and bending strength of concrete in Rigid Pavement
}

\author{
Sugeng Wiyono ${ }^{2}$, Zulhendri ${ }^{1}$, Mohd.Alfajrizal ${ }^{1}$, Anas Puri ${ }^{2}$ \\ ${ }^{1}$ Mahasiswa Program Magister Teknik Sipil, Universitas Islam Riau \\ ${ }^{2}$ Dosen Program Magister Teknik Sipil, Universitas Islam Riau \\ wiyonouir@gmail.com
}

\begin{abstract}
Abstrak
Semen merupakan suatu bahan pembentuk beton yang berperan sangat penting untuk mencapai mutu yang direncanakan. Selain pemilihan jenis merek semen, salah satu cara untuk mendapatkan kualitas beton yang baik yaitu dengan cara melakukan perawatan. penelitian ini bertujuan untuk mengetahui sejauh mana kualitas tiga merek semen terhadap kuat tekan dan kuat lentur beton disamping itu juga bertujuan untuk mengetahui seberapa besar perbedaan kekuatan dari masing- masing merek semen terhadap beton yang dirawat dan tanpa dirawat. Pada penelitian ini menggunakan metode eksperimental yang sesuai dengan SK SNI T-15-1990-03. Penelitian ini menggunakan semen Padang, semen Holcim, dan semen Bosowa, dengan menggunakan jenis perawatan perendaman pada sampel beton, pengujian yang dilakukan adalah pengujian kuat tekan dan kuat lentur dengan mutu rencana fc $30 \mathrm{MPa}$ dengan umur 7, 14, 28, dan 56 hari, untuk masing-masing umur dibuat 3 benda uji dirawat dan 3 benda uji tidak dirawat. Dari hasil uji kuat tekan rata-rata semen padang memiliki kekuatan 32,65 $\mathrm{MPa}$, semen holcim 31,33 MPa dan semen bosowa 30,86 MPa. Sedangkan untuk pengujian kuat lentur semen padang 4,35 $\mathrm{MPa}$, semen holcim 4,23 $\mathrm{MPa}$ dan semen bosowa 4,18MPa, sementara beton yang tidak dirawat memiliki nilai lebih rendah dari beton yang dirawat.. Dari hasil pengujian tersebut dapat dilihat bahwa pemakaian merek semen perlu diperhatikan karakteristiknya serta perawatan mempunyai konstribusi yang cukup besar dalam mendapatkan mutu beton hasil pelaksanaan.
\end{abstract}

Kata kunci: Perkerasan Kaku, Semen, Perawatan, Kuat Tekan, Kuat Lentur

\begin{abstract}
The cement concrete as product that consit of several element which is important for achieve the quality that be planed. To choose same kriteria for getting the good quality of concrete, one of way are choosing the brand of cement and doing curing. Therfore, the aim of this research is ro know about the strength of of each brand of cement toword cured and uncuret concrete. This research used cement padang, cement holcim, cement bosowa with soaking treatments of concrete samples. The used of the tests are compresive and bending strength of concrete with using quality plan $f_{c}$ ' $30 \mathrm{MPa}$ and age range 7, 14, 28 and 56 days. The cement padang is better than others cement and by getting the the highest value also found cement Padang has the sensitivity to the curing. Cement Bosowa got high strength at the beginning of the age and for cement Holcim is relativity stable with the age. From the researh, knowed that is important the selection of cement brand and curing to get the good result consist of the quality by yhe first plan.
\end{abstract}

Keywords : Rigid Pavement, cement, Curing, Compresive and bending strength 


\section{PENDAHULUAN}

\section{Latar Belakang}

Perkembangan dalam dunia konstruksi perkerasan jalan sangat pesat sehingga para produsen berlomba lomba menciptakan teknologi baru dalam bidang kostruksi salah satunya semen. Produk Semen terdiri dari banyak unsur yang terkandung didalamnya sehingga yakini memiliki kelebihan dan kekurangan, dengan berbagai merek semen yang dugunakan akan dapat mempengaruhi kekuatan tekan dan kekuatan lentur beton.

Sekarang ini pembangunan jalan di Indonesia baik jalan arteri atau jalan kolektor banyak sekali menggunakan konstruksi jalan dengan konstruksi

perkerasan kaku, dan pada jenis perkerasaan ini untuk menguji kekuatan perkerasan beton dilakukan uji kuat tekan dan kuat lentur, berbagai jenis merek semen yang digunakan diyakini memberikan pengaruh besar terhadap kuat tekan dan kuat lentur perkerasan beton.

Tujuan yang diharapkan dari penelitian ini adalah untuk memperoleh gambaran sejauh mana perbedaan kualitas beton dari masing-masing merek semen yang dipakai terhadap hubungan serta perbandingan kuat tekan dan kuat lentur pada rencana umur beton 7, 14, 28 dan 56 hari, salah satu merek semen yang digunakan adalah produk semen luar negeri.

\section{Rumusan Masalah}

Bagaimana kualitas beton penggunaan berbagai merek semen (Semen Padang, Semen Holcim, Semen bosowa, Semen Conch) dengan tipe yang sama (PCC) terhadap uji kuat tekan dan uji kuat lentur dengan menggunakan sumber material yang sama.

\section{Tujuan Penelitian}

Tujuan yang diharapkan dicapai dari kegiatan penelitian ini adalah untuk memperoleh gambaran sejauh mana perbedaan kualitas mutu beton dari masing-masing merek semen yang dipakai untuk mendapatkan mutu beton rencana $\left(f^{\prime} c=30 \mathrm{MPa}\right)$ yang dihasilkan dari penggunaan Semen Padang, Semen Holcim, semen bosowa dan Semen Conch serta bagaimana pengaruh dilakukan perawatan atau tidak dilakukan perawatan terhadap mutu beton.

\section{Batasan Masalah}

Material agregat diperoleh dari Quari Kampar, mutu beton yang dikaji adalah mutu $\mathrm{fc}^{\prime}=30 \mathrm{MPa}$. Penelitian ini tidak mengkaji unsur kimia dan mineral yang terkandung di dalam semen

\section{TINJAUAN PUSTAKA Penelitian Sebelumnya}

1. Bassarudin, (2017). "Kajian Kolerasi Antara Kuat Tekan Terhadap Kuat Lentur Beton Pada Perkerasan Kaku”. Dari hasil uji kuat lentur pada umur 28 hari untuk beton $f_{c}{ }^{\prime}=30 \mathrm{MPa}$ adalah $4,21 \mathrm{MPa}, f c^{\prime}=35 \mathrm{MPa}$ adalah 4,45 $\mathrm{MPa}$, dan $f c^{\prime}=40 \mathrm{MPa}$ adalah 4,79 $\mathrm{MPa}$. Perbandingan pengujian kuat tekan beton dengan alat tekan Universal Testing Machine dan Hammer Test didapat hasil bahwa pengujian dengan alat tekan UTM lebih rendah hasilnya jika dibandingkan dengan hasil pengujian dengan alat Hammer Test.

2. Pasaribu (2010), "Analisi Penggunaan Berbagai Merk Semen Untuk Pembuatan Beton $f_{c}{ }^{\prime}=20 \mathrm{MPa}$ Dengan Mengunakan Agregat Dari Binjai”. Penelitian ini untuk memperoleh gambaran sejauh mana perbedaan kualitas mutu beton dari masing-masing tipe dan merek semen yang dipakai untuk mendapatkan mutu beton rencana $\left(f c^{\prime}=20 \mathrm{MPa}\right)$ yang dihasilkan dari penggunaan Semen Holcim, Semen Tiga Roda, Semen Andalas dan Semen Padang. Dari penelitian ini di dapat Semen Holcim $f c^{\prime}=20,12 \mathrm{MPa}$, Semen Tiga Roda $f_{c}{ }^{\prime}=23,13 \mathrm{MPa}$, Semen Andalas $f_{c^{\prime}}{ }^{\prime}=25,20 \mathrm{MPa}$, semen padang $f_{c^{\prime}}{ }^{\prime}=$ 
23,41 MPa. Dapat dilihat semen Tiga Roda memiliki Kuat tekan lebih tinggi dari semen lainnya. Sedangkan pada Semen Holcim memilki kuat tekan dengan nilai yang paling rendah.

3. Sutandar (2013), "Pengaruh Pemeliharaan (Curing) Pada Kuat Tekan Beton Normal”. Beton adalah campuran antara semen, agregat, dan air yang menyebabkan terjadinya suatu hubungan yang erat antara bahan-bahan tersebut. Beton yang baik adalah bila setiap partikel agregat, baik kasar maupun halus terbungkus seluruhnya oleh pasta semen dan semua rongga diantara partikel-partikel agregat tersebut terisi seluruhnya oleh pasta semen. Pasta semen ini selain mengisi pori-pori diantara butiran agregat halus juga bersifat sebagai perekat dalam proses pengerasan, sehingga butiran- butiran agregat saling terikat dengan kuat dan terbentuklah suatu massa yang padat. Metode yang dilakukan pada penelitian ini yaitu dengan metode ACI modifikasi dan SK SNI. Hasil penelitian menunjukkan bahwa nilai kuat tekan rata-rata pada umur 7 hari yang dirawat 9,785 Mpa dan yang tidak dirawat 8,229 Mpa. Sedangkan umur 28 hari yang dirawat 12,875 Mpa dan yang tidak dirawat 11,195 Mpa. Berdasarkan nilai yang diperoleh tersebut bahwa kuat tekan beton dengan dilakukan perawatan dengan cara direndam ternyata mempunyai kekuatan dan akhir yang lebih tinggi dari pada dibiarkan di udara terbuka/tanpa dirawat.

4. Syaifudin (2017), "Pengaruh Variasi Perawatan Beton Terhadap Sifat Mekanik High Volume Fly Ash Concrete Untuk Memproduksi Beton Kuat Tekan Normal". Perawatan beton adalah proses yang bertujuan untuk menjaga kelembaban beton agar beton tidak terlalu cepat kehilangan air. Dalam penelitian ini beton High Volume Fly Ash (HVFA) dilakukan beberapa variasi perawatan yaitu dengan cara perawatan direndam, disiram, dan ditutup karung basah, dengan mutu beton yang direncanakan adalah f'c 22,5 $\mathrm{MPa}$, menggunakan metode ACI. Pengujian yang dilakukan adalah pengujian kuat tekan dan serapan air. Dari hasil penelitian didapatkan nilai kuat tekan rata-rata beton normal dengan perawatan direndam sebesar 18,26 MPa pada umur 28 hari dan 20,24 MPa pada umur 56 hari, lebih tinggi dibandingkan dengan beton $H V F A$ dengan variasi perawatan.

5. Wagianto (2010), "Studi Eksperimen Kuat Tekan Beton Dan Kuat Tarik Belah Beton Normal Dengan Semen Berbeda Merk". Pada penelitian ini menggunakan semen merk Holcim, Merah Putih dan Tiga Roda pada adukan beton normal yang bertujuan untuk mengetahui perbandingan nilai kuat tekan beton dan kuat Tarik belah beton yang dihasilkanoleh beton dengan semen merek Holcim, Merah Putih dan Tiga Roda.Pada Penelitian ini berupa studi eksperimen atau percobaan, mengacu pada metode ASTM C33.2004. Dari hasil kuat tekan beton di dapat semen Holcim fc =35,574 Mpa, semen Merah Putih didapat $\mathrm{fc}=33,215 \mathrm{Mpa}$ dan semen Tiga Roda didapat $\mathrm{fc}=28,780 \mathrm{Mpa}$.

\section{METODOLOGI}

Metode yang diterapkan dalam penelitian ini adalah metode eksperimental yaitu suatu metode yang dilakukan dengan mengadakan suatu percobaan secara langsung untuk mendapatkan suatu data atau hasil yang menghubungkan antara variabel yang 
diselidiki. Pada penelitian ini ekperimen dilakukan di laboratorium pengujian yang dilakukan dalam penelitian ini meliputi pengujian bahan, pengujian kuat tekan dengan menggunakan alat uji tekan beton dan pengujian kuat lentur dengan alat uji lentur.

\section{Lokasi Penelitian}

Penelitian dilakukan pada laboratorium PT. Lutvindo Wijaya Perkasa yang terletak di jalan raya Garuda Sakti KM 05 Kota Pekanbaru arah Petapahan.

\section{Bahan}

Bahan yang digunakan dalam penelitian ini antara lain:

a. Agregat kasar (batu pecah) diperoleh dari Quary Kampar, hasil Stone Cruser dari PT. Lutvindo Wijaya Perkasa

b. Agregat halus, diperoleh dari Quary Danau Bingkuang.

c. Semen yang digunakan adalah Semen Tipe PCC Seman Padang, Semen Holcim dan Semen Conch.

d. Air, air sumur bor PT. Lutvindo Wijaya Perkasa

\section{Peralatan Uji}

Alat Uji Kuat Tekan

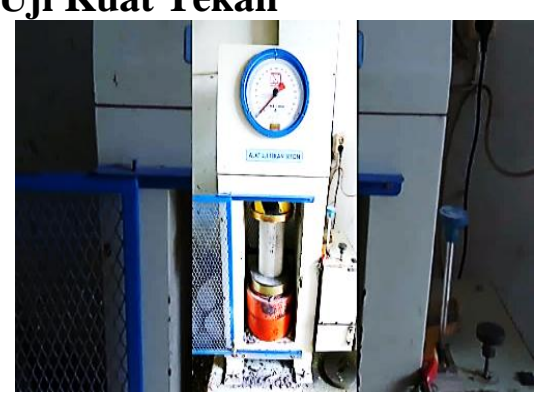

Gambar 1. Alat Tekan (Compresion Testing Machine)

\section{Alat Uji Kuat Lentur}

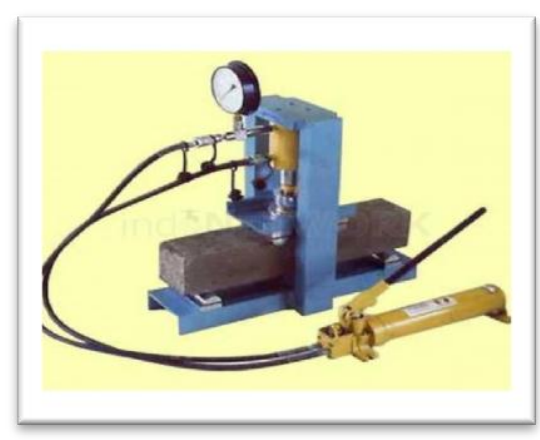

Gambar 2. Alat Tekan (Bending Testing Machine)

\section{HASIL DAN PEMBAHASAN}

Berdasarkan hasil pengujian beton sesuai dengan hasil yang diperoleh nilai kuat tekan rata-rata beton pada umur 7 hari, 14 hari , 28 sampai pada umur 56 hari.

Tabel 1. Hasil pengujian kuat tekan beton

\begin{tabular}{|l|l|c|c|c|c|c|}
\hline & & & \multicolumn{4}{|c|}{ Kuat Tekan Rata-rata (MPa) } \\
\cline { 5 - 8 } No. & Merek Semen & Mutu Beton & 7 hari & 14 hari & 28 hari & 56 hari \\
\hline 1. & Padang & $\mathrm{fc}=30 \mathrm{MPa}$ & 23.02 & 29.25 & 31.89 & 32.65 \\
\hline 2. & Holcim & $\mathrm{fc}=30 \mathrm{MPa}$ & 22.27 & 28.12 & 30.38 & 31.33 \\
\hline 3. & Conch & $\mathrm{fc}=30 \mathrm{MPa}$ & 22.46 & 28.87 & 30.76 & 30.95 \\
\hline
\end{tabular}

Dari Tabel 1. dapat dilihat bahwa kuat tekan rata-rata paling tinggi dari ketiga merek semen menurut umur berturut-turut adalah Semen Padang, kemudian Semen Conch dan yang terendah adalah Semen Holcim.

Kecenderungan peningkatan kekuatan beton seiring pertambahan umur terlihat pada hasil pengujian di atas. 


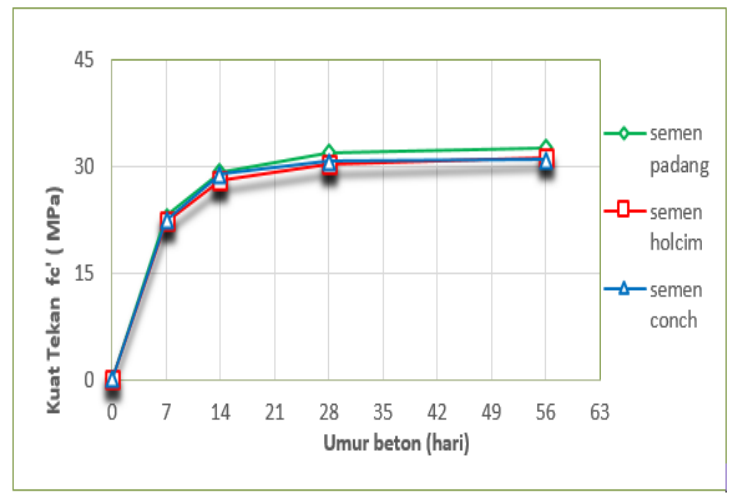

Gambar 1. Hasil uji kuat tekan beton

Tabel 2. Hasil pengujian kuat lentur beton

\begin{tabular}{|c|c|c|c|c|c|c|}
\hline \multirow[b]{2}{*}{ No. } & \multirow[b]{2}{*}{ Merek Semen } & \multirow[b]{2}{*}{ Mutu Beton } & \multicolumn{4}{|c|}{ Kuat lentur Rata-rata (MPa) } \\
\hline & & & 7 hari & 14 hari & 28 hari & 56 hari \\
\hline 1. & Padang & $f c^{\prime}=30 \mathrm{MPa}$ & 3.59 & 4.14 & 4.31 & 4.35 \\
\hline 2. & Holcim & $f c^{\prime}=30 \mathrm{MPa}$ & 3.58 & 4.01 & 4.17 & 4.23 \\
\hline 3. & Conch & $\mathrm{fc}^{\prime}=30 \mathrm{MPa}$ & 3.59 & 4.16 & 4.23 & 4.27 \\
\hline
\end{tabular}

Berdasarkan data pada Tabel 2. di atas terlihat bahwa kuat lentur beton mutu $f^{\prime} c=$ $30 \mathrm{MPa}$ tertinggi menurut umur adalah Semen Padang. Kecenderungan peningkatan kekuatan lentur beton seiring pertambahan umur terlihat jelas pada hasil pengujian di atas. Hal ini terjadi pada tiga merek semen beton pada gambar 2

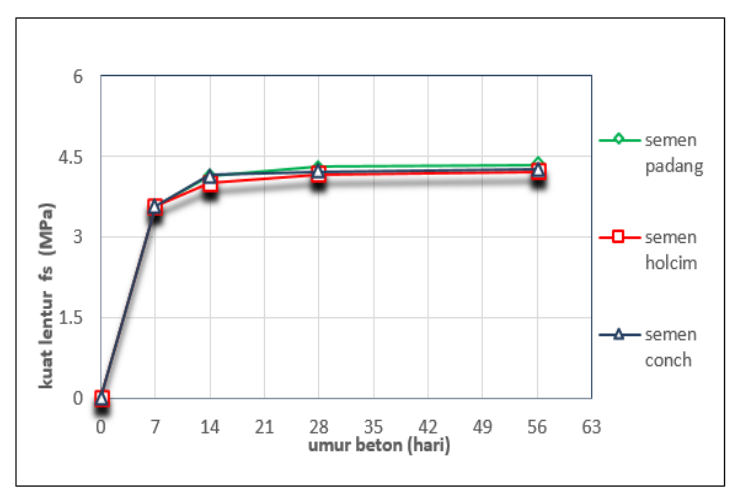

Gambar 2. Hasil uji kuat lentur beton

\section{Kuat Tekan}

Melalui hasil pengujian kuat tekan pada sampel beton, maka dapat diketahui perkembangan kekuatan tekan dari tiap umur beton dengan cara perawatan perendaman dan tanpa pemberian perawatan untuk semua merek semen.

Tabel 3. Hasil uji kuat tekan dengan dan tanpa perawatan.

\begin{tabular}{|c|c|c|c|}
\hline Umur & $\begin{array}{c}\begin{array}{c}\text { KuatTe } \\
\text { kan }\end{array} \\
\text { Dirawat }\end{array}$ & $\begin{array}{c}\text { Kuat } \\
\text { Tekan } \\
\text { Tanpa } \\
\text { Dirawat }\end{array}$ & \multirow[t]{2}{*}{ Keterangan } \\
\hline (Hari) & $\begin{array}{c}f c^{\prime} \\
(\mathbf{M P a})\end{array}$ & $f c^{\prime}(\mathbf{M P a})$ & \\
\hline 7 & 23,02 & 20,48 & \multirow{4}{*}{$\begin{array}{c}f c 30 \\
\text { Semen } \\
\text { Padang }\end{array}$} \\
\hline 14 & 29,25 & 22,08 & \\
\hline 28 & 31,89 & 22,18 & \\
\hline 56 & 32,65 & 22,08 & \\
\hline 7 & 22,27 & 20,19 & \multirow{4}{*}{$\begin{array}{c}f c 30 \\
\text { Semen } \\
\text { Holcim }\end{array}$} \\
\hline 14 & 28,12 & 21,89 & \\
\hline 28 & 30,38 & 21,99 & \\
\hline 56 & 31,33 & 21,99 & \\
\hline 7 & 23,31 & 20,67 & \multirow{4}{*}{$\begin{array}{c}f c 30 \\
\text { Semen } \\
\text { Bosowa }\end{array}$} \\
\hline 14 & 30,86 & 22,08 & \\
\hline 28 & 30,67 & 21,99 & \\
\hline 56 & 30,67 & 21,99 & \\
\hline
\end{tabular}

Berdasrkan tabel diatas, dapat dibuat grafik seperti berikut.

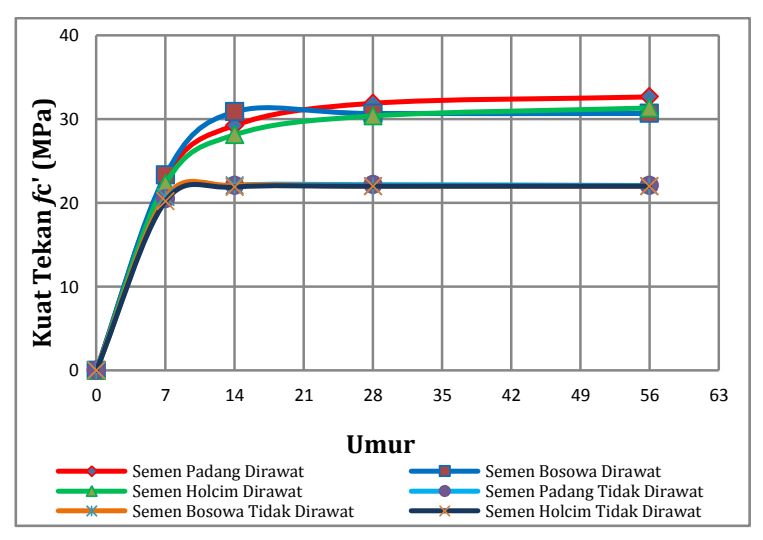

Gambar 3. Hasil uji kuat tekan dengan \& tanpa perawatan 


\section{A. Semen Padang}

Tabel 4. Hasil pengujian kuat tekan beton dengan \& tanpa perawatan

\begin{tabular}{|c|c|c|c|c|}
\hline Umur & $\begin{array}{c}\text { Kuat } \\
\text { Tekan } \\
f c^{\prime} \\
(\mathbf{M P a})\end{array}$ & $\begin{array}{c}\text { Kuat } \\
\text { Tekan } \\
f \mathbf{c}^{\prime} \\
(\mathbf{M P a})\end{array}$ & $\begin{array}{c}\text { Rasio } \\
\text { Kehilang } \\
\text { an } \\
\text { Kekuata } \\
\text { n }\end{array}$ & \multirow[t]{2}{*}{$\begin{array}{l}\text { Jenis } \\
\text { Smen }\end{array}$} \\
\hline (Hari) & $\begin{array}{c}\text { Diraw } \\
\text { at }\end{array}$ & $\begin{array}{c}\text { Tanp } \\
\text { a } \\
\text { Diraw } \\
\text { at }\end{array}$ & $\%$ & \\
\hline 7 & 23,02 & 20,48 & $11 \%$ & \multirow{4}{*}{$\begin{array}{c}\text { Seme } \\
\mathrm{n} \\
\text { Padan } \\
\mathrm{g}\end{array}$} \\
\hline 14 & 29,25 & 22,08 & $24 \%$ & \\
\hline 28 & 31,89 & 22,18 & $30 \%$ & \\
\hline 56 & 32,65 & 22,08 & $32 \%$ & \\
\hline
\end{tabular}

Dari tabel diatas dapat dijelaskan bahwa sangat pentingnya pemberian perawatan bagi beton, karena nilai kuat tekan yang tidak dilakukannya perawatan tidak mencapai dari mutu rencana $f \mathrm{c} 30$ MPa dan berada dibawah dari nilai kuat tekan yang dilakukkannya perawatan disetiap umurnya, kecenderungan persentase kehilangan kekuatan yang dialami pada beton yang tidak dilakukannya perawatan meningkat seiring dengan bertambahnya umur. Untuk lebih jelas dapat didilihat pada gambar sebagai berikut.

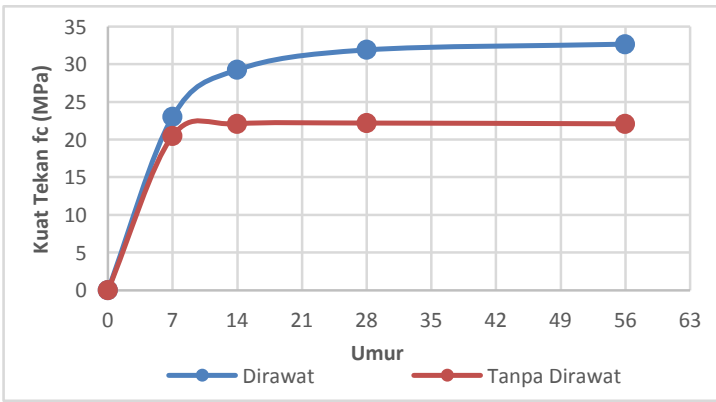

Gambar 4. Hasil uji kuat tekan

\section{B. Semen Holcim}

Hasil pengujian kuat tekan beton rata-rata untuk semen holcim dapat dilihat pada Tabel 5 dibawah.

Tabel 5. Hasil uji kuat tekan semen Holcim

\begin{tabular}{|c|c|c|c|c|}
\hline Umur & $\begin{array}{c}\text { Kuat } \\
\text { Tekan } \\
f c^{\prime} \\
\text { (MPa) }\end{array}$ & $\begin{array}{c}\text { Kuat } \\
\text { Tekan } \\
f c^{\prime} \\
(\mathbf{M P a})\end{array}$ & $\begin{array}{c}\text { Rasio } \\
\text { Kehilan } \\
\text { gan } \\
\text { Kekuata } \\
\text { n }\end{array}$ & \multirow[t]{2}{*}{$\begin{array}{c}\text { Jenis } \\
\text { Sem } \\
\text { en }\end{array}$} \\
\hline (Hari) & $\begin{array}{c}\text { Diraw } \\
\text { at }\end{array}$ & $\begin{array}{c}\text { Tanpa } \\
\text { Diraw } \\
\text { at }\end{array}$ & $\%$ & \\
\hline 7 & 22,27 & 20,19 & $9 \%$ & \multirow{4}{*}{$\begin{array}{c}\text { Sem } \\
\text { en } \\
\text { Holc } \\
\text { im }\end{array}$} \\
\hline 14 & 28,12 & 21,89 & $22 \%$ & \\
\hline 28 & 30,38 & 21,99 & $28 \%$ & \\
\hline 56 & 31,33 & 21,99 & $30 \%$ & \\
\hline
\end{tabular}

Berdasarkan tabel diatas nilai kuat tekan yang tidak dilakukannya perawatan tidak mencapai dari mutu rencana $f \mathrm{c}$ 30MPa dan berada dibawah dari nilai kuat tekan yang dilakukkannya perawatan disetiap umurnya, kecenderungan kehilangan kekuatan yang dialami pada beton yang tidak dilakukannya perawatan meningkat seiring dengan bertambahnya umur. Untuk lebih jelas dapat didilihat pada gambar sebagai berikut.

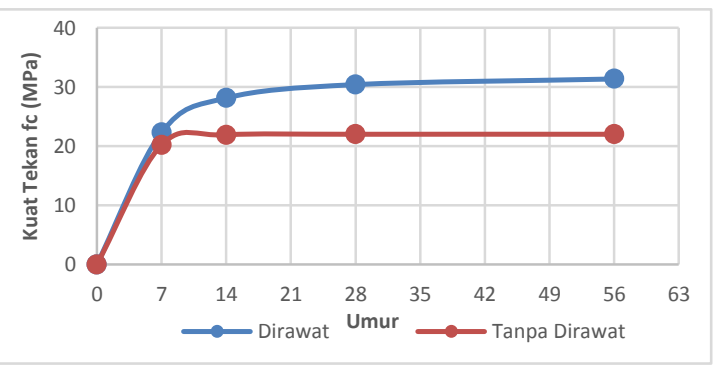

Gambar 5. Kuat tekan Holcim 


\section{Semen Holcim}

Hasil pengujian kuat tekan beton rata-rata untuk semen bosowa dapat dilihat pada Tabel 6 dibawah.

Tabel 6. Kuat tekan semen Bosowa

\begin{tabular}{|c|c|c|c|c|}
\hline Umur & $\begin{array}{c}\text { Kuat } \\
\text { Tekan } \\
f c^{\prime} \\
\text { (MPa) }\end{array}$ & $\begin{array}{c}\text { Kuat } \\
\text { Tekan } \\
f c^{\prime} \\
(\mathbf{M P a})\end{array}$ & $\begin{array}{c}\text { Rasio } \\
\text { Kehilan } \\
\text { gan } \\
\text { Kekuata } \\
\text { n }\end{array}$ & \multirow{2}{*}{$\begin{array}{c}\text { Jenis } \\
\text { Seme } \\
\mathbf{n}\end{array}$} \\
\hline (Hari) & $\begin{array}{c}\text { Diraw } \\
\text { at }\end{array}$ & $\begin{array}{c}\text { Tanpa } \\
\text { Diraw } \\
\text { at }\end{array}$ & $\%$ & \\
\hline 7 & 23,31 & 20,67 & $11 \%$ & \multirow{4}{*}{$\begin{array}{c}\text { Seme } \\
n \\
\text { Boso } \\
\text { wa }\end{array}$} \\
\hline 14 & 30,86 & 22,08 & $28 \%$ & \\
\hline 28 & 30,67 & 21,99 & $28 \%$ & \\
\hline 56 & 30,67 & 21,99 & $28 \%$ & \\
\hline
\end{tabular}

Dari tabel 6 diatas dapat dijelaskan bahwa nilai kuat tekan yang tidak dilakukannya perawatan tidak mencapai dari mutu rencana $f \mathrm{c} 30 \mathrm{MPa}$ dan berada dibawah dari nilai kuat tekan yang dirawat disetiap umurnya, kecenderungan kehilangan kekuatan yang dialami pada sampel beton yang tidak dilakukannya perawatan meningkat dari umur 7 hari. Untuk lebih jelas dapat didilihat pada gambar sebagai berikut.

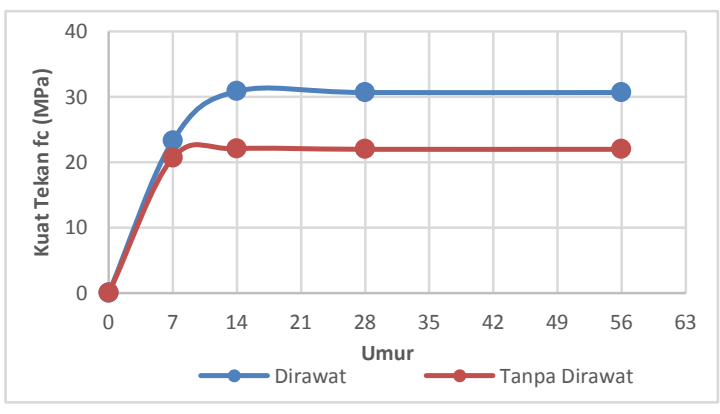

Gambar 6. Hasil uji kuat tekan semen Bosowa

\section{Kuat Lentur}

Dengan melakukan pengeujian kuat lentur beton pada benda uji balok, dapat diketahui perkembangan terhadap kekuatan lentur dari tiap umur beton dengan perawatan dan tanpa perawatan.

Hasil pengujian kuat lentur beton dengan nilai rata-rata yang diperoleh untuk semua merek semen dapat dilihat pada Tabel dibawah.

\begin{tabular}{|c|c|c|c|}
\hline Umur & $\begin{array}{c}\text { Kuat } \\
\text { lentur } \\
\text { Dirawat }\end{array}$ & $\begin{array}{c}\text { Kuat } \\
\text { lentur } \\
\text { Tanpa } \\
\text { Dirawat }\end{array}$ & Keterangan \\
\hline (Hari) & $f \mathbf{s}^{\prime}(\mathrm{Mpa})$ & $f \mathbf{s}^{\prime}$ (Mpa) & \\
\hline 7 & 3,59 & 3,19 & \multirow{4}{*}{$\begin{array}{c}f \mathrm{c} 30 \\
\text { Semen } \\
\text { Padang }\end{array}$} \\
\hline 14 & 4,14 & 3,33 & \\
\hline 28 & 4,31 & 3,43 & \\
\hline 56 & 4,35 & 3,46 & \\
\hline 7 & 3,58 & 3,14 & \multirow{4}{*}{$\begin{array}{c}f c 30 \\
\text { Semen } \\
\text { Holcim }\end{array}$} \\
\hline 14 & 4,01 & 3,27 & \\
\hline 28 & 4,17 & 3,37 & \\
\hline 56 & 4,23 & 3,40 & \\
\hline 7 & 3,64 & 3,23 & \multirow{4}{*}{$\begin{array}{c}f c 30 \\
\text { Semen } \\
\text { Bosowa }\end{array}$} \\
\hline 14 & 4,18 & 3,36 & \\
\hline 28 & 4,16 & 3,35 & \\
\hline 56 & 4,17 & 3,35 & \\
\hline
\end{tabular}

Berdasrkan tabel diatas, dapat dibuat grafik seperti berikut.

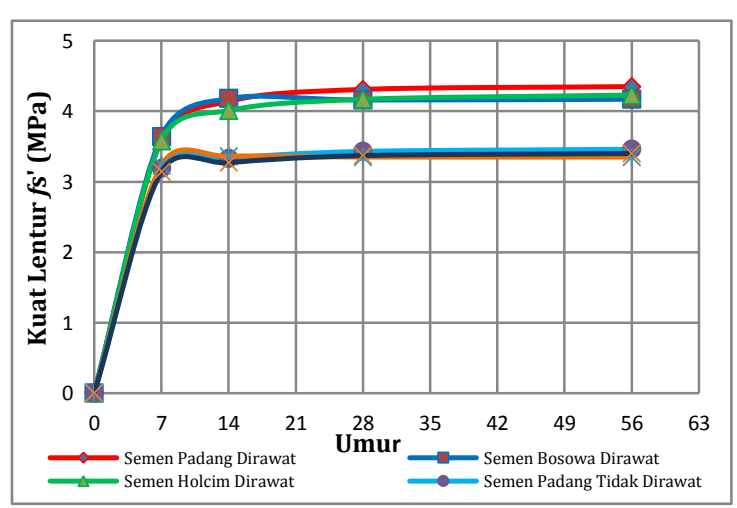

Gambar 7. Hasil uji kuat tekan berbagai kondisi 


\section{A. Semen Padang}

Hasil pengujian kuat lentur beton rata-rata untuk semen padang dapat dilihat pada Tabel 1 dibawah.

Tabel 7. Hasil uji kuat lentur semen Padang

\begin{tabular}{|c|c|c|c|c|}
\hline $\begin{array}{c}\text { Umu } \\
\mathbf{r}\end{array}$ & $\begin{array}{c}\text { Kuat } \\
\text { Lentur } \\
f s^{\prime} \\
\text { (MPa) }\end{array}$ & $\begin{array}{c}\text { Kuat } \\
\text { Lentur } \\
f s^{\prime} \\
\text { (MPa) }\end{array}$ & $\begin{array}{c}\text { Rasio } \\
\text { Kehilana } \\
\text { gn } \\
\text { Kekuata } \\
\text { n }\end{array}$ & \multirow{2}{*}{$\begin{array}{c}\text { Jenis } \\
\text { Seme } \\
\mathbf{n}\end{array}$} \\
\hline $\begin{array}{l}\text { (Har } \\
\text { i) }\end{array}$ & $\begin{array}{c}\text { Dirawa } \\
\mathbf{t}\end{array}$ & $\begin{array}{c}\text { Tanpa } \\
\text { Dirawa } \\
\mathbf{t}\end{array}$ & $\%$ & \\
\hline 7 & 3,59 & 3,19 & $11 \%$ & \multirow{4}{*}{$\begin{array}{c}\text { Seme } \\
n \\
\text { Pada } \\
\text { ng }\end{array}$} \\
\hline 14 & 4,14 & 3,33 & $20 \%$ & \\
\hline 28 & 4,31 & 3,43 & $20 \%$ & \\
\hline 56 & 4,35 & 3,46 & $20 \%$ & \\
\hline
\end{tabular}

Dari tabel diatas nilai kuat lentur yang tidak dirawat berada dibawah dari nilai kuat lentur yang dilakukannya perawatan untuk disetiap umurnya, nilai tersebut tidak mampu mencapai dari nilai mutu yang telah direncanakan yaitu fc 30 mpa, kecenderungan kehilangan kekuatan yang dialami pada beton yang tidak dilakukannya perawatan meningkat di umur 7 hari. Untuk lebih jelasnya dapat didilihat pada gambar berikut.

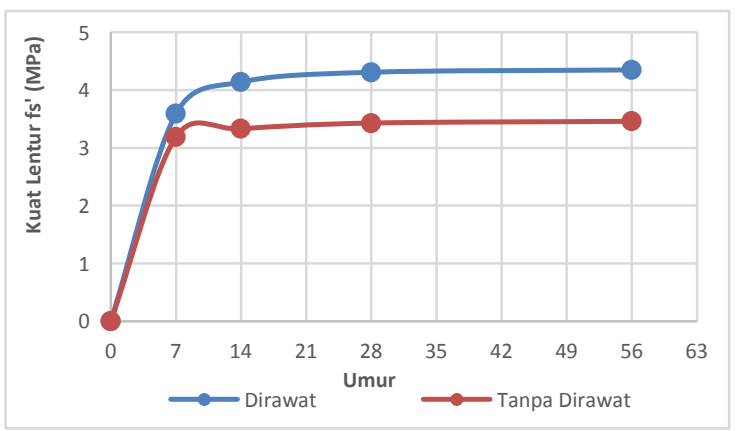

Gambar 8. Hasil uji kuat lentur semen Padang

\section{B. Semen Holcim}

Hasil pengujian kuat lentur beton rata-rata untuk semen holcim dapat dilihat pada Tabel 9 dibawah.

Tabel 9. Hasil uji kuat lentur semen Holcim

\begin{tabular}{|c|c|c|c|c|}
\hline $\begin{array}{l}\text { Um } \\
\text { ur }\end{array}$ & $\begin{array}{c}\text { Kuat } \\
\text { Lentur } \\
f_{s^{\prime}} \\
(\mathrm{MPa})\end{array}$ & $\begin{array}{c}\text { Kuat } \\
\text { Lentur } \\
f_{s^{\prime}} \\
(\mathrm{MPa})\end{array}$ & $\begin{array}{c}\text { Rasio } \\
\text { Penuru } \\
\text { nan } \\
\text { Kekuat } \\
\text { an }\end{array}$ & \multirow{2}{*}{$\begin{array}{c}\text { Jenis } \\
\text { Sem } \\
\text { en }\end{array}$} \\
\hline $\begin{array}{c}\text { (Ha } \\
\text { ri) }\end{array}$ & $\begin{array}{c}\text { Diraw } \\
\text { at }\end{array}$ & $\begin{array}{c}\text { Tanpa } \\
\text { Diraw } \\
\text { at }\end{array}$ & $\%$ & \\
\hline 7 & 3,58 & 3,14 & $12 \%$ & \multirow{4}{*}{$\begin{array}{c}\text { Sem } \\
\text { en } \\
\text { Holc } \\
\text { im }\end{array}$} \\
\hline 14 & 4,01 & 3,27 & $18 \%$ & \\
\hline 28 & 4,17 & 3,37 & $19 \%$ & \\
\hline 56 & 4,23 & 3,40 & $20 \%$ & \\
\hline
\end{tabular}

Berdasarkan tabel nilai kuat lentur yang tidak dirawat berada dibawah dari nilai kuat lentur yang dirawat disetiap umurnya, kecenderungan persentase kehilangan kekuatan yang dialami pada beton yang tidak dilakukannya perawatan mengalami peningkatan seiring dengan bertambahnya umur pada benda uji beton. Untuk lebih jelas dapat didilihat pada gambar berikut.

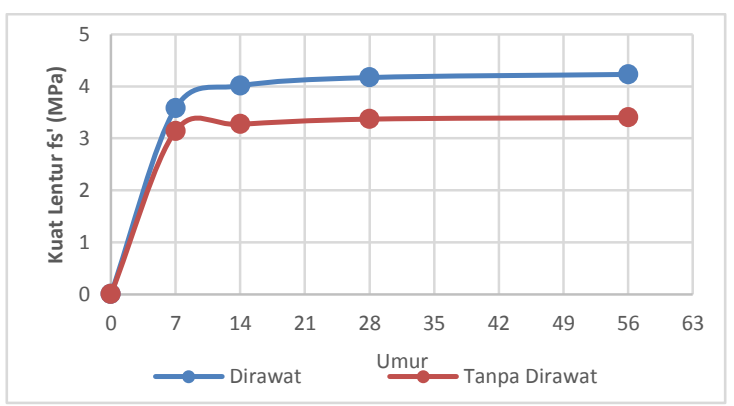

Gambar 9. Hasil uji semen holcim 


\section{Semen Bosowa}

Hasil pengujian kuat lentur beton semen bosowa dapat dilihat pada Tabel 3 dibawah.

Tabel 10. Hasil uji lentur semen Bosowa

\begin{tabular}{|c|c|c|c|c|}
\hline $\begin{array}{c}\text { Um } \\
\text { ur }\end{array}$ & $\begin{array}{c}\text { Kuat } \\
\text { Lentu } \\
\text { r } f s^{\prime} \\
\text { (MPa } \\
\text { ) }\end{array}$ & $\begin{array}{c}\text { Kuat } \\
\text { Lentu } \\
\mathbf{r} f s^{\prime} \\
(\mathrm{MPa} \\
)\end{array}$ & $\begin{array}{c}\text { Rasio } \\
\text { Kehilan } \\
\text { gan } \\
\text { Kekuata } \\
\text { n }\end{array}$ & \multirow[t]{2}{*}{$\begin{array}{c}\text { Jenis } \\
\text { Semen }\end{array}$} \\
\hline $\begin{array}{c}\text { (Ha } \\
\text { ri) }\end{array}$ & $\begin{array}{l}\text { Dira } \\
\text { wat }\end{array}$ & $\begin{array}{c}\text { Tanp } \\
\text { a } \\
\text { Dira } \\
\text { wat }\end{array}$ & $\%$ & \\
\hline 7 & 3,64 & 3,23 & $11 \%$ & \multirow{4}{*}{$\begin{array}{l}\text { Semen } \\
\text { Bosowa }\end{array}$} \\
\hline 14 & 4,18 & 3,36 & $20 \%$ & \\
\hline 28 & 4,16 & 3,35 & $19 \%$ & \\
\hline 56 & 4,17 & 3,35 & $20 \%$ & \\
\hline
\end{tabular}

Berdasarkan tabel diatas dapat dijelaskan bahwa pentingnya pemberian perawatan bagi beton, karena nilai kuat lentur yang tidak dirawat berada dibawah dari nilai kuat lentur yang dirawat disetiap umurnya, Untuk lebih jelas dapat didilihat pada gambar sebagai berikut.

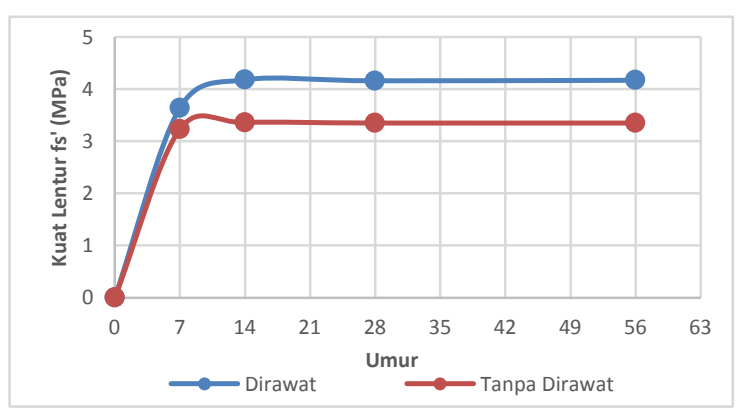

Gambar 10. Hasil uji lentur semen Bosowa

\section{KESIMPULAN DAN SARAN Kesimpulan}

Berdasarkan hasil pengujian dan pengamatan langsung yang telah dilakukan dapat disimpulkan sebagai berikut:
1. Berdasarkan penelitian dengan faktor air semen yang sama, Semen Holcim encer (slump lebih tinggi), sedangkan Semen Padang dan semen Conch memiliki nilai slump sama,

2. Untuk uji kuat tekan dan lentur Semen Padang lebih unggul dibandingkan dengan Semen Conch dan Semen Holcim pada semua umur 7, 14, 28, 56 hari

3. Ternyata terdapat hubungan hasil uji kuat tekan dan kuat lentur, semen padang konsisten unggul hasil uji kuat tekan dan kuat lentur daripada terhadap Semen Conch dan Semen Holcim

4. Dari hasil uji kuat tekan rata-rata $f \mathrm{c}$ 30 untuk semen padang 32,65 MPa, semen holcim 31,33 $\mathrm{MPa}$ dan semen bosowa 30,86 MPa. Sedangkan untuk pengujian beton yang tidak dirawat hanya mencapai nilai kuat tekan tertinggi yaitu 22,18 MPa. Dari hasil uji lentur semen padang 4,35 $\mathrm{MPa}$, semen holcim 4,23 MPa dan semen bosowa 4,18 MPa. Sedangkan untuk pengujian beton yang tidak dirawat hanya mencapai nilai kuat lentur tertinggi yaitu 3,46 MPa.

5. Pemberian perawatan sangat berpengaruh terhadap hasil pengujian, dengan melakukan perawatan dihasilkan lebih tinggi dari pada beton yang tidak dilakukan perawatan pada semua jenis semen yang digunakan.

\section{Saran-Saran}

Dari kesimpulan di atas maka dapat dibuat suatu saran-saran sebagai berikut:

1. Alat uji kuat tekan Compression Testing Machine dan Bending Testing Machine harus benar-benar akurat, serta pembacaan jarum beban maksimal 
harus teliti dan cermat (harus dikalibrasi dulu).

2. Untuk penelitian selanjutnya perbandingan komposisi Nano Semen teknologi baru untuk mendapatkan kuat tekan beton dan kuat lentur yang jauh lebih baik dan mudah dalam pengerjaan.

3. Untuk dapat melakukan penelitian lebih lanjut atau lebih mengembangkan pada penelitian ini seperti pemilihan atau pemakaian jenis semen yang lebih beragam lagi, jenis dan asal material yang berbeda, serta dengan mutu dan umur pengujian yang lebih beragam lagi. Dan metode perawatan yang berbeda.

4. Semoga dengan adanya penelitian ini dapat menjadi masukan bagi pelaku jasa konstruksi dalam pemilihan jenis semen berdasarkan nilai kekuatan yang dimiliki serta

\section{DAFTAR PUSTAKA}

Antoni, Paul Nugraha, 2007, Teknologi Beton, dari Material, Pembuatan, ke Beton Kinerja Tinngi, Surabaya

ASTM C33.2004. "Standard Specification For Concrete Aggregates", Annual Books of ASTM Standard, USA.

Badan Standarisasi Nasional. 1990. SNI 03-1971-1990, Metode Pengujian Kadar Air Agregat. Bandung.

Badan Standarisasi Nasional. 2008. SNI 1972:2008, "Cara Uji Slump

Beton. Bandung".

Badan Standarisasi Nasional. 2008. SNI 2417:2008, “Cara Uji Keausan Agregat Dengan Mesin Abrasi Los Angeles. Bandung

Badan Standarisasi Nasional. 1990. SNI 03-1974-1990, Metode Pengujian Kuat Tekan Beton. Bandung. BMPTTSSI-KONTEKS 5, seminar nasional. (2011) "Pengunaan Pozolan Berukuran Nano Un tuk menghasilkan Beton Mutu Tinggi
(HIGH STRENGTH CONCRETE) Ramah Lingkungan".

Badan Standarisasi Nasional. 2011. SNI 4431:2011, Metode Pengujian Kuat Tarik Lentur Beton. Bandung.

Dinas Pekerjaan Umum (2012),“

Spesifikasi Umum Bina Marga 2010 revisi 3", Dinas Pekerjaan Umum Bidang Bina Marga, Jakarta, 2012

Dian Wahyudi dkk., 2016. "PerbandinganKuat Tekan Beton dengan Menggunakan Dua Jenis Semen dan Variasinya"

Depertemen Pekerjaan Umum., 1989, Pedoman Beton 1989.

Kementerian Pekerjaan Umum., 2008, Puslitbang Jalan Dan Jembatan Indonesia. Bandung.

Sutandar Erwin, 2013, Pengaruh Pemeliharaan (Curing) Pada Kuat Tekan Beton Normal. Universitas TanjungPura, Pontianak.

Syaifudin Achmad, 2017, Pengaruh Variasi Perawatan Beton Terhadap Sifat Mekanik High Volume Fly Ash Concrete Untuk Memproduksi Beton Kuat Tekan Normal. Universitas Muhammadyah Surakarta, Surakarta.

Tjokrodimuljo, K., 1992, Buku Ajaran Teknologi Beton, Yogyakarta.

Wagianto., 2010, Studi Eksperimen Kuat Tekan Beton Dan Kuat Tarik Belah Beton Normal Dengan Semen Berbeda Merk. Universitas Tanjungpura, Pontianak.

Wiyono, S., 2009, "Bahan Konstruksi Dan Material Jalan” Bahan Ajar Kuliah Sifat Dan Bahan Konstruksi Jalan Program Pascasarjana Teknik Sipil Universitas Islam Riau, Pekanbaru.

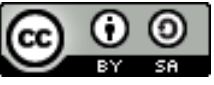
This is an open access article which means that all content is freely available without charge to the user or his/her institution. Jurnal Saintis allows the author(s) to hold the copyright without restriction. The copyright in the text of individual articles (including research articles, opinion articles, and abstracts) is the property of their respective authors distributed under the terms of the Creative Commons Attribution-ShareAlike 4.0 International License(https://creativecommons.org/licenses/by-sa/4.0/) which permits unrestricted use, distribution, and reproduction in any medium. Users are allowed to read, download, copy, distribute, search, or link to full-text articles in this journal without asking by giving appropriate credit, provide a link to the license, and indicate if changes were made. 